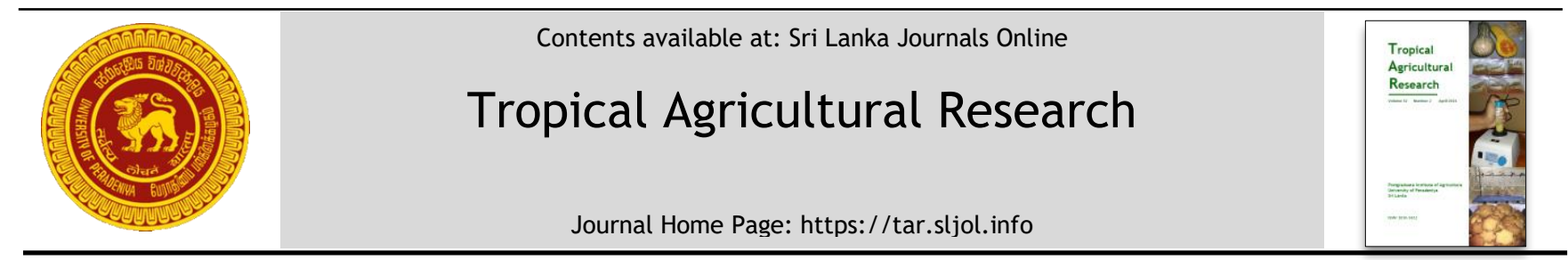

\title{
Bioactive Properties of Fish Protein Hydrolysates from Amazon Sailfin Catfish (Pterygoplichthys pardalis) from the Victoria Reservoir in Sri Lanka
}

\author{
S.K.D. Wijesinghe ${ }^{1 *}$, E.D.N.S. Abeyrathne ${ }^{2}$, J.K. Vidanarachchi ${ }^{3}$ and R.P.N.P. Rajapakse ${ }^{4}$ \\ ${ }^{1}$ Postgraduate Institute of Agriculture, University of Peradeniya, Peradeniya, Sri Lanka. \\ ${ }^{2}$ Department of Animal Science, Faculty of Animal Science \& Export Agriculture, Uva Wellassa University, Sri Lanka. \\ ${ }^{3}$ Department of Animal Science, Faculty of Agriculture, University of Peradeniya, Peradeniya, Sri Lanka. \\ ${ }^{4}$ Department of Food Science \& Technology, Faculty of Agriculture, University of Peradeniya, Sri Lanka
}

\section{ARTICLE INFO}

\section{Article history:}

Received: 12 August 2020

Revised version received: 7 November 2020

Accepted: 17 January 2021

Available online: 1 April 2021

\section{Keywords:}

Bioactive properties,

Enzymatic hydrolysis,

Fish protein extract (FPE),

Fish protein hydrolysate (FPH)

\section{Citation:}

Wijesinghe, S. K. D., Abeyrathne, E.D.N.S., Vidanarachchi, J.K. and Rajapakse, R.P.N.P. (2021). Bioactive Properties of Fish Protein Hydrolysates from Amazon Sailfin Catfish (Pterygoplichthys pardalis) from Victoria Reservoir in Sri Lanka. Tropical Agricultural Research, 32(2): 219-228.

DOI: http://doi.org/10.4038/tar.v32i2.8469

Wijesinghe, S. K. D.

https://orcid.org/0000-0002-3732-7790

\section{ABSTRACT}

Pterygoplichthys pardalis is an underutilized by-catch fish species considered as an invasive fish, which is a potential threat to Sri Lankan freshwater fishery industry. This study attempted to produce bioactive fish protein hydrolysates (FPH) using $P$. pardalis. Acid-aided aqueous extract of fish protein was produced and the best protein extraction (PE) was selected. The lyophilized extracts were hydrolyzed using pepsin, papain and trypsin enzymes (1:100), and were subjected to analyze antioxidant properties by DPPH scavenging assay and TBARS assay, metal chelation activity and antimicrobial activity by agar well diffusion method. The $15 \%$ citric acid sample showed the highest $(\mathrm{p}<0.05)$ PE yield $(1.95 \% \pm 0.04 \mathrm{w} / \mathrm{w})$. The pepsin $(0$ hour) treated hydrolysate showed the highest $(\mathrm{p}<0.05)$ radical scavenging activity $(79.71 \% \pm 5.19)$. None of the hydrolysates exhibited antioxidant properties against TBARS and showed no significant difference $(\mathrm{p}>0.05)$ in the ferrous chelating activity (pepsin (0 hour): 52.31\% \pm 0.93 , papain ( 9 hours): $50.95 \% \pm 1.17$ ). Antibacterial activity against E. coli was positive in all hydrolysates, where pepsin ( 0 hour) hydrolysate showed the highest activity against E. coli. This concludes, FPHs of acidsoluble protein of $P$. pardalis contain antioxidant properties, iron-binding activity and antibacterial activity.

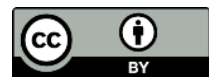

\footnotetext{
* Corresponding author: krishani.pm@gmail.com
} 


\section{INTRODUCTION}

Fish is a highly nutritious food, which has a high demand among consumers (Ojutiku et al., 2009). It is a rich source of balanced and easily digestible protein particularly sulphur containing amino acids, omega-3 long chain polyunsaturated fatty acids, vitamins and a low caloric density food compared to terrestrial animal meat (Tacon and Metian, 2013). It provides about $15 \%$ of the average per capita intake of animal protein of more than 4.5 billion consumers (Béné et al., 2015).

Only few species of total landed fish are commercially valuable where, significant proportion of total catch remains unused. Inherent characteristics such as unattractive flavor, color, heavy bony structure, high fat content and texture are the reasons for no market value of some fish species called by-catch or underutilized fish species. By-products generated in fish processing industries (e.g. heads, fins, skin, trimmings, bones, frames and viscera) and the fish species with no commercial value are generally discarded (Venugopal et al., 1995). However, in addition to fish flesh of edible fish species, value added products are developed using fish processing leftovers and the underutilized fish species as raw materials. Such value-added products include fish protein hydrolysates, pet food, fish silage, fertilizer, fish oil etc. (Ramírez-Ramírez et al., 2008).

Pterygoplichthys pardalis, Amazon sailfin catfish (Common called Scavenger fish) is a native fish species to the Amazon river basin of Peru and Brazil. Though they are usually bottom dwellers, they can breathe air from the water surface during dry periods and when live in waters of low dissolved oxygen. This fish species is popular around the world as an aquarium pet due to its characteristic attractive appearance and also as an aquarium tank cleaner to remove moss (Rao and Sunchu, 2017).

Numerous exotic fish species have been introduced either accidentally or intentionally into Asian freshwaters and some have been considered as alien invasive species (AIS) due to their potential threats to the freshwater biodiversity in the region (Welcomme, 1988). In Sri Lanka, inland fishery was initiated in 1951 with the introduction of Oreochromis mossambicus (Tilapia). However, at present, it has been confined to man-made lakes called reservoirs and is basically dependent on exotic cichlid species (Fernando, 2000). P. pardalis is an invasive, exotic and underutilized by-catch fish species introduced through the ornamental fish trade. Currently, it has become a potential threat to Sri Lankan freshwater fishery. P. pardalis can be found in many inland reservoirs including Victoria reservoir, Polgolla reservoir, Kala wewa, Balalu wewa, Kandalama wewa and Usgala Siyambangamuwa wewa. (Kumudinie and Wijeyaratne, 2005). Infestation of $P$. pardalis in reservoirs of Sri Lanka makes a substantial negative impact on the commercial fishery by entangling as a by-catch fish in commercial gillnets while making gillnets less effective for catching target species.

Hydrolysis methods are developed to convert fish protein into most acceptable and marketable forms (Halldorsdottir et al., 2014). Enzymatic hydrolysis is known to be an efficient method of producing bioactive peptides from fish proteins. Production of fish protein hydrolysates (FPH) and use of peptides as an ingredient of functional foods is a recent technology which is gaining popularity. The potential bioactive properties linked with them include antimicrobial, antioxidant, immunomodulatory, antihypertensive and neuroactive properties (Alasalvar et al., 2002). It has been proved that, under controlled enzymatic hydrolysis, the bioactive peptides are released from the protein, yielding functional hydrolysates. The substrate, proteases used, and the degree of hydrolysis are the main factors that govern functional properties of resulting hydrolysate. The type of enzyme employed affects on the cleavage patterns of the peptide bonds in protein. (Jun et al., 2004).

Though a considerable amount of information is available on functional properties such as antioxidant, antimicrobial and metal chelation of peptides derived from FPH, the potential use of these bioactive peptides in pharmaceutical and food industry needs to be widely investigated. Therefore the current study aimed to produce FPH from $P$. pardalis using food grade proteases (trypsin, pepsin, papain), and to investigate the process condition (hydrolysis time) that led to high bioactive properties (antioxidant activity, metal chelating activity and antimicrobial activity).

\section{METHODOLOGY}

\section{Sample collection}

Female P. pardalis (average body weight: 250-350 g, average body length: $25-30 \mathrm{~cm}$ ) were collected from Victoria reservoir in Digana (Central province, Sri Lanka). Newly harvested fish samples were transported under frozen condition and stored at $-21{ }^{\circ} \mathrm{C}$ until experiment was carried out. Olive oil was purchased from a local supermarket. 


\section{Preparation of fish protein extract (FPE)}

Processed fish samples, after removing head, skin and gut, were chopped into small pieces and minced (mixer grinder, model: HL1643/04, India) before taking samples to prepare FPE. Distilled water was added to (DW: Mince 4:1 (w/w)) minced sample (Perera et al., 2018) and homogenized (mixer grinder, model: HL1643/04, India) for $60 \mathrm{~s}$. Citric acid monohydrate powder was added to homogenate at five different concentrations $(0,5$, $10,15$, and $20 \%(\mathrm{w} / \mathrm{w}))$ and blended using a mixer grinder with medium power. Then, the samples were kept in an open-air shaker (Model: OS-2000, Thermofisher Scientific, Germany) at $150 \mathrm{rpm} \mathrm{min}^{-}$ 1 for $1 \mathrm{~h}$ with continuous stirring (at $4{ }^{\circ} \mathrm{C}$ ), followed by incubation for overnight at $4 \stackrel{\circ}{ } \mathrm{C}$ in a refrigerator while allowing maximum solubilization of proteins. Incubated extracts were centrifuged (model: SORVALL ST 40R, Thermofisher Scientific, Germany) at $3400 \mathrm{rpm}, 4^{\circ} \mathrm{C}$ for 20 minutes and the supernatants were collected. Method of acid aided solubilization of proteins described by Choi and Park (2002) was slightly modified in preparing FPE. Entire procedure was carried out below $10^{\circ} \mathrm{C}$. The $\mathrm{pH}$ of the supernatants was adjusted to neutral $\mathrm{pH}(\mathrm{pH}$ 7) with $3 \mathrm{M} \mathrm{NaOH}$ to neutralize acidic $\mathrm{pH}$ and samples were lyophilized for $48 \mathrm{~h}$ using freeze drier (model: 05512, iLShinBioBase Co.Ltd., Korea).

The best citric acid concentration for the acid-aided protein extraction was analysed using $10 \%$ Sodium Dodecyl Sulphate Poly Acrylamide Gel Electrophoresis (SDS-PAGE) (QNX-700, C.B.S. Scientific) according to Sambrook and Russell (2006) and yield analysis of FPE. The yield of FPE was calculated using the equation 1.

Yield $\%=\frac{\mathrm{W} 1}{\mathrm{w} 0} \times 100$

where, $\mathrm{W}_{1}$ is the final weight of lyophilized sample and $W_{0}$ is the initial weight of FPE

\section{Production of fish protein hydrolysates (FPH)}

Fish protein hydrolysates (FPH) were produced by enzymatic hydrolysis of the FPE according to the method described in Ramakrishnan et al. (2013). FPE $(20 \mathrm{mg} / \mathrm{mL}$ solution) were enzymatically hydrolyzed by three exogenous enzymes; trypsin (pH 7.8), pepsin ( $\mathrm{pH} 2.5)$, and papain (pH 6.5) at their optimum $\mathrm{pH}$ conditions (pH meter; model: PL-700PV, EZDO, Taiwan). The enzyme to sample ratio was $1: 100(\mathrm{w} / \mathrm{v})$ and mixtures were incubated at $37^{\circ} \mathrm{C}$ for six different time lags; $0,3,6$, 9, 12 and $24 \mathrm{~h}$. Then, the enzymes were heat inactivated at $100{ }^{\circ} \mathrm{C}$ for 15 min using a dry heat block before adjusting the $\mathrm{pH}$ to neutral and lyophilizing for $48 \mathrm{~h}$ using freeze drier. Best hydrolysates of each enzyme were determined using 15\% SDS-PAGE (Sambrook and Russell, 2006) and selected hydrolysates were used for the determination of bioactive properties.

\section{Analysis of bioactive properties of FPH}

\section{Determination of antioxidant properties}

The DPPH (2,2-Diphenyl-1-picrylhydrazyl) radical scavenging activity assay was conducted according to Liu et al. (2010) with slight modifications, to measure the antioxidant activity of FPH. The assay was carried out by making a mixture of $700 \mu \mathrm{L}$ of hydrolyzed sample (20 mg FPH dissolved in $1 \mathrm{~mL}$ DW) and $300 \mu \mathrm{L}$ of DPPH solution which was prepared by dissolving $4 \mathrm{mg}$ of DPPH (Sigma Aldrich-Germany) powder in $100 \mathrm{~mL}$ of methanol (Sigma Aldrich-USA), then shaking thoroughly and incubating for 30 minutes in dark conditions. Absorbance was determined at $517 \mathrm{~nm}$ using UVSpectrophotometer (model: UV-2005, Thermofisher Scientific, Germany). The free radical scavenging activity was calculated using equation 2.

$\mathrm{SA}(\%)=\left[1-\frac{\mathrm{As}-\mathrm{A} 1}{\mathrm{~A} 0}\right] \times 100$

where, SA is the free radical scavenging activity, As is the absorbance of the sample, A1 is the absorbance of the sample with Methanol, and A0 is the absorbance of the DPPH-Methanol solution (Control).

Lipid peroxidation level was determined by Thiobarbituric acid reactive substances assay (TBARS) according to Abeyrathne et al. (2014) with some modifications as described here. An oilin-water emulsion was prepared by homogenizing (Model: D-500, SCILOGEX, USA) $1 \mathrm{~g}$ of olive oil, 100 $\mu \mathrm{L}$ of Tween-20 and $100 \mathrm{~mL}$ of distilled water for 2 minutes in an ice bath. The emulsion was incubated at $37^{\circ} \mathrm{C}$ for few minutes (Model: YCW-010E). Then, $8 \mathrm{~mL}$ of the emulsion was added to $1 \mathrm{~mL}$ of lyophilized FPH (dissolved in distilled water (20 $\mathrm{mg} / \mathrm{mL}$ )) and $1 \mathrm{~mL}$ of distilled water in $15 \mathrm{~mL}$ falcon tube, and incubated at $37^{\circ} \mathrm{C}$ for $16 \mathrm{~h}$. After incubation, $1 \mathrm{~mL}$ of sample was transferred to 50 $\mathrm{mL}$ falcon tube, and $2 \mathrm{~mL}$ of TBA/TCA (Sigma Aldrich-USA) (20 mM TBA/15\% TCA) solution and $50 \mu \mathrm{L}$ of $10 \%$ Butylated Hydroxyanisole in $90 \%$ ethanol were added and vortex mixed (Model: ZX3, 
VELP Scientifica, USA). The mixture was incubated at $90{ }^{\circ} \mathrm{C}$ in a water bath for 15 min to develop the color. Later, sample was cooled in an ice bath for 10 min and centrifuged (model: ST-40R) at $3000 \mathrm{rpm}$, $5^{\circ} \mathrm{C}$ for $15 \mathrm{~min}$. The absorbance of the solution was measured at $532 \mathrm{~nm}$ against the blank prepared with $2 \mathrm{~mL}$ of TBA/TCA solution, $50 \mu \mathrm{L}$ of $10 \%$ Butylated Hydroxyanisole in $90 \%$ ethanol and 1 $\mathrm{mL}$ of distilled water. The TBARS value was expressed as milligrams of malondialdehyde per liter of emulsion (MDA mg/ L).

\section{Metal chelation activity of FPH}

Metal chelation properties of FPH were measured using Fe (II) chelating activity. It was analyzed using ferrozine method described in Abeyrathne et al. (2014) with slight modifications. The protocol involved vortex mixing of $100 \mu \mathrm{L}$ of FPH $(20 \mathrm{mg}$ FPH/ $1 \mathrm{~mL} \mathrm{DW),} 900 \mu \mathrm{L}$ of distilled water, and $1 \mathrm{~mL}$ of $10 \mathrm{ppm} \mathrm{Fe}^{2+}\left(\mathrm{FeSO}_{4}\right)$ in a $15 \mathrm{~mL}$ Falcon tube. Then, the mixture was incubated for 5 minutes at room temperature before adding $900 \mu \mathrm{L}$ of $11.3 \%$ TCA and centrifuging at $2500 \times \mathrm{g}$ for $10 \mathrm{~min}$ to remove proteins and peptides present in the sample. Then, $1 \mathrm{~mL}$ of the supernatant was transferred to a disposable culture tube, and $1 \mathrm{~mL}$ of distilled water, $800 \mu \mathrm{L}$ of $10 \%$ ammonium acetate (Fisher Scientific), and $200 \mu \mathrm{L}$ of Ferroin color indicator were added before vortex mixing. After 5 min of incubation at room temperature, the absorbance of each sample was measured at 562 nm. The Fe (II) chelating activity of FPHs were calculated using the equation 3 .

$$
\mathrm{CA}(\%)=\left[1-\frac{\mathrm{As}}{\mathrm{Ab}}\right] \times 100
$$

where, CA is the Fe(II) chelating activity, As is the absorbance of the sample, $\mathrm{Ab}$ is the absorbance of the blank.

\section{Antibacterial properties of FPH}

Antibacterial properties of hydrolyzed samples were examined using agar well diffusion method (Bendjeddou et al., 2016). Locally isolated food borne Escherichia coli (E. coli) bacterial culture was used to determine antimicrobial properties. Isolated $E$. coli bacteria culture was first inoculated in EMB agar plates and incubated at $37^{\circ} \mathrm{C}$ for $48 \mathrm{~h}$. A loop full of this cultured isolate was then inoculated in a previously prepared EC broth and incubated at $37^{\circ} \mathrm{C}$ for $24 \mathrm{~h}$.

A concentration series were prepared using each of the FPH as $10,000,5,000,2,500,1,250$ and 625 ppm. Initially, $15-20 \mathrm{~mL}$ of nutrient agar was poured into the incubated petri plates and allowed to solidify. Then, the bacterial culture was inoculated by streaking them on agar surface using a sterile cotton bud. Afterwards, agar was punched with sterile cork bored of $4 \mathrm{~mm}$ size and $100 \mu \mathrm{L}$ of sample was micro-pipetted into that bore (well), kept for $30 \mathrm{~min}$ and plates were incubated at $37^{\circ} \mathrm{C}$ for $48 \mathrm{~h}$. Finally, the plates were observed for bacterial inhibition zones to analyze the antimicrobial activity. Augmentin was antibiotic used as the positive control whereas autoclaved distilled water was used as a negative control. The concentration of the positive control was equivalent to the lowest concentration of the series.

\section{Statistical analysis}

Experimental design was Complete Randomized Design (CRD) with five replicates. Data were analyzed with SAS statistical software by employing one-way ANOVA and Tukey's method $(\mathrm{p}<0.05)$.

\section{RESULTS AND DISCUSSION}

\section{Acid-aided solubilization of FPE}

In the present study, organic acid (citric acid) was used as a replacement to hydrochloric $(\mathrm{HCl})$ and sulfuric $\left(\mathrm{H}_{2} \mathrm{SO}_{4}\right)$ acids for the solubilization of proteins. In acid-aided solubilization of fish protein, typically $\mathrm{HCl}$ or $\mathrm{H}_{2} \mathrm{SO}_{4}$ is used. This could lead to significant loss in its functional properties over the alkali-aided solubilization and leave health concerns (Kristinsson and Rasco, 2000). Hence, there is a trend of substituting $\mathrm{HCl}$ and $\mathrm{H}_{2} \mathrm{SO}_{4}$ acids with an organic acid such as citric acid, acetic acid in acid-aided protein recovery studies.

\section{Yield analysis of FPE}

According to the yield analysis, citric acid concentration has significantly affected on the protein yield $(p<0.05)$. The protein extract yields are shown in Figure 1. Soluble protein yield in the supernatant has increased with the increase of citric acid concentration up to $15 \%$ citric acid and slightly decreased. The lowest yield was observed in the control ( $0 \%$ citric acid) sample though there was no significant difference of the yield between control and 5\% citric acid contained samples, whereas, the highest yield was observed in 15\% citric acid contained sample. Consequently, the 


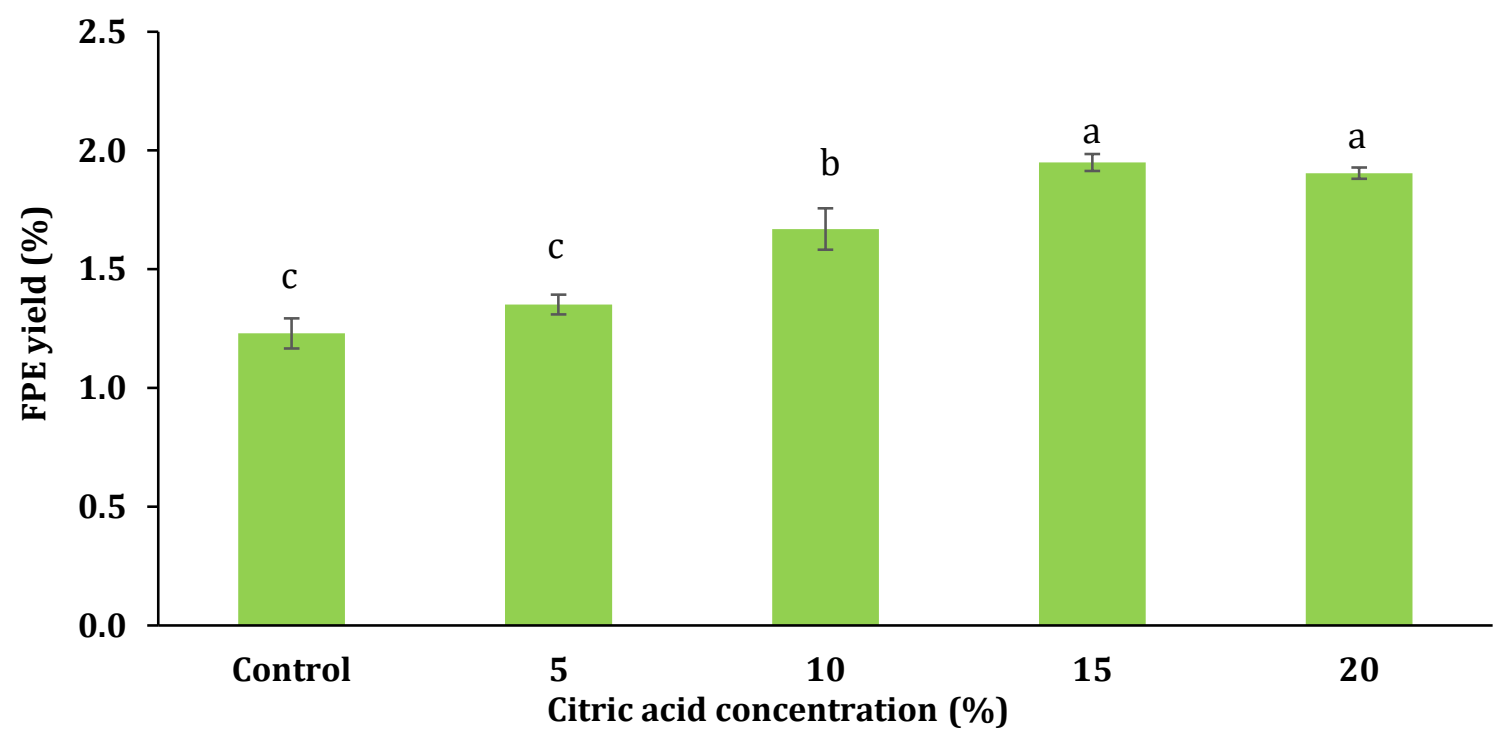

Figure 1. Yield analysis of acid-aided fish protein extract $(\% \mathrm{w} / \mathrm{w})$

citric acid concentration (15\%) that produced the highest yield was selected as the best acid concentration to prepare FPE based on the yield analysis.According to Hrynets et al. (2011), the highest protein solubility of mechanically separated turkey meatwith citric acid was revealed at $\mathrm{pH} 2.5$ among the different acidic conditions investigated. The protein solubility was slightly high when extractions were performed at higher citric acid concentrations (low acidic $\mathrm{pH}$ ) than at lower concentrations (high acidic $\mathrm{pH}, \sim 3.5$ $\mathrm{pH}$ ). In the current study, $\mathrm{pH}$ of the citric acid treated samples were ranged between $\mathrm{pH} 2.5$ to 2.9. Moreover, the efficiency of acid-aided solubilization of protein might be due to the additional recovery of sarcoplasmic proteins along with the myofibrillar proteins under low $\mathrm{pH}$ condition. These results clearly demonstrate the basic principle of the $\mathrm{pH}$-shifting method of protein recovery, where an additional extraction of sarcoplasmic proteins occurs (Ingadottir, 2004).

The band patterns of SDS-PAGE (10\%) of FPE were also analyzed to determine the best citric acid concentration to prepare FPE. According to Plate 1, which illustrates the gel electrophoretic patterns of extracted lyophilized proteins with different acid concentrations, all five acid extracted protein samples exhibited protein bands with a similar pattern indicating that proteins extracted from $P$. pardalis might be of same types. The thickness of the protein bands slightly increased with the increasing concentration of acids. Due to the additional recovery of sarcoplasmic proteins along with the myofibrillar proteins under low $\mathrm{pH}$ condition, thickness of the protein bands and smears were slightly increased with the increase of citric acid concentration (with the reduction of $\mathrm{pH}$ ). There was no visually difference found between bands of $15 \%$ and $20 \%$ citric acid treated samples. Accordingly, 15\% citric acid sample was selected for protein extracts preparation.

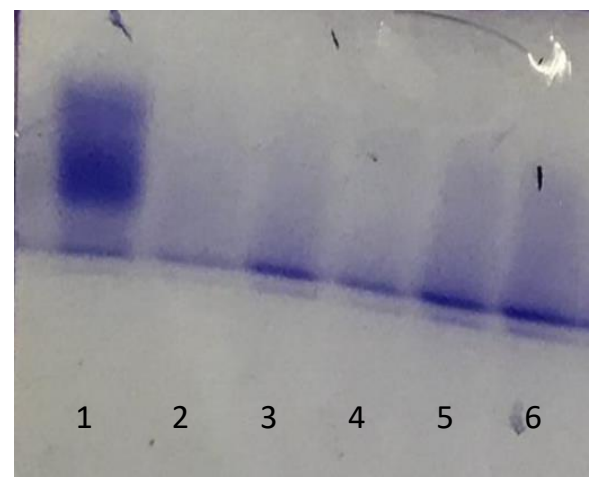

Plate 1. 10\% SDS-PAGE image of FPE. Note: Lane 1: Broad range protein molecular weight marker (10 $\mu \mathrm{L})$, Lane 2: Control (0\% Citric acid) FPE, Lane 3: 10\% Citric acid added FPE, Lane 4: 5\% Citric acid added FPE, Lane 5: 15\% Citric acid added FPE, Lane 6: 20\% Citric acid added FPE

\section{Enzymatic hydrolysis of acid soluble fish proteins}

Before hydrolysis, all the FPE samples were opaque in nature. Later, all the FPH produced by enzymatic hydrolysis were converted to clear light brown color solutions. It showed a slight coagulation at the bottom of Eppendorf tube after the heat denaturation process due to the thermal denaturation of proteins (Boye et al., 1997). Since 
coagulation occurred in almost all the FPH samples, it could have not influenced the decision of selecting the best time lag for each enzymatic hydrolysis. In the enzymatic hydrolysis, fish proteins breakdown into soluble peptides and amino acids, and insoluble compounds by proteolytic enzymes (Damodaran et al., 2008). Enzymatic hydrolysis is the efficient method of protein recovery from the animal and fish in food processing industries (Bhaskar et al., 2008).

The Plates 2, 3 and 4 demonstrate the 15\% SDSPAGE gel images for FPH of trypsin, pepsin and papain enzymes, respectively.

The shred (Lane 1; control) which is well matched with FPE has produced a protein band in all three SDS-PAGE images, since it has not subjected to hydrolysis process and remained as the protein itself. In Plate 2, peptide bands could be observed in trypsin treated FPH with all the time lags, which is compatible with control (FPE) suggesting that no complete hydrolysis was occurred in trypsin added samples. It might be due to the presence of trypsin inhibitory compounds of protein in the acid-aided extract of $P$. pardalis protein or else due to the complex enzymatic hydrolysis process including the $\mathrm{pH}$, temperature and time lag of hydrolysis.

There were no clear demarcations of protein bands in pepsin hydrolysis (Plate 3). Absence of protein bands and presence of smears revealed that all the proteins have been hydrolysed properly converted to FPH by the action of pepsin enzyme. In comparison, the Plate 4 carries no protein bands but the smears in the last three lanes (Lane 5, 6, 7) while the lanes 2,3 and 4 appeared similar to lane 1. Accordingly, papain $9 \mathrm{~h}$ and pepsin $0 \mathrm{~h}$ were determined as the best hydrolysing time lags for respective two enzymes. Since the enzymes are substrate specific, the time required to complete hydrolyzation of extracted proteins vary with different enzymes (Hu et al., 2013). Thus, only the fish protein hydrolysates derived from pepsin $(0 \mathrm{~h})$ and papain $(9 \mathrm{~h})$ hydrolysis were used for the determination of bioactive properties.

\section{Bioactive properties of FPH}

\section{Antioxidant activity of FPH}

In the DPPH assay, protein hydrolysates reduce the DPPH radicals into a yellow-coloured compounds due to capturing an electrons or hydrogen by the DPPH radicals to become a stable diamagnetic molecule (Liu et al., 2010). Based on this principle, the antioxidant activity of a compound can be expressed as its ability to scavenge the DPPH radical (Centenaro et al., 2011). Accordingly,

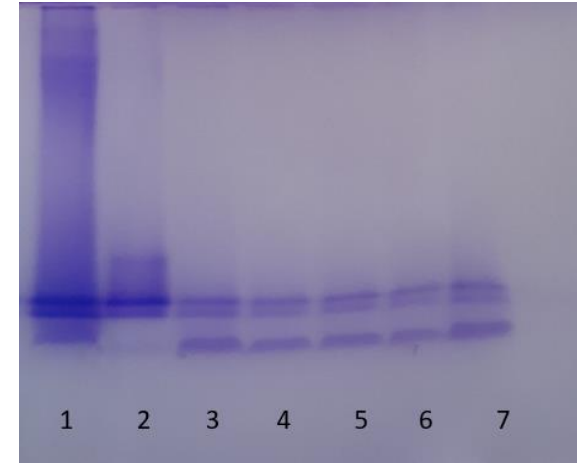

Plate 2. 15\% SDS-PAGE image of trypsin treated hydrolysates. Note: Lane 1: Control (FPE), Lane 2: 0 hour (FPH), Lane 3: 3 hours (FPH), Lane 4: 6 hours (FPH), Lane 5: 9 hours (FPH), Lane 6: 12 hours (FPH), Lane 7: 24 hours (FPH)

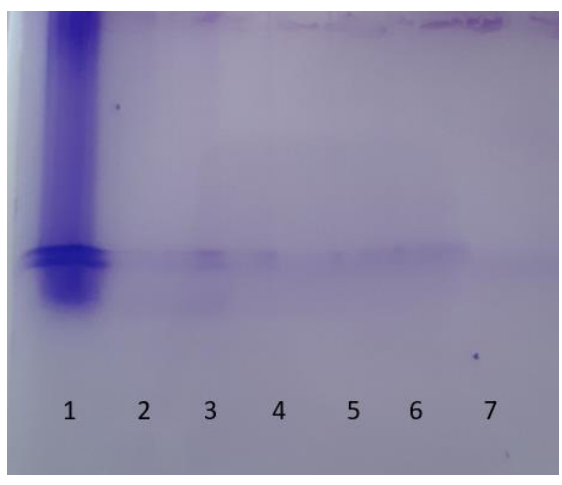

Plate 3. 15\% SDS-PAGE image of pepsin treated hydrolysates. Note: Lane 1: Control (FPE), Lane 2: 0 hour (FPH), Lane 3: 3 hours (FPH), Lane 4: 6 hours (FPH), Lane 5: 9 hours (FPH), Lane 6: 12 hours (FPH), Lane 7: 24 hours (FPH)

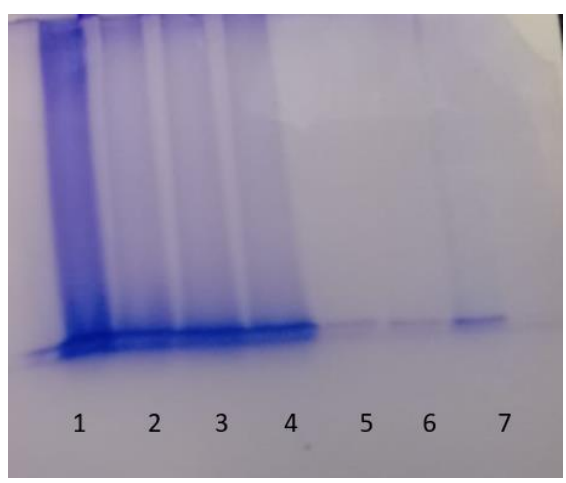

Plate 4. 15\% SDS-PAGE image of papain treated hydrolysates. Note: Lane 1: Control (FPE), Lane 2: 0 hour (FPH), Lane 3: 3 hours (FPH), Lane 4: 6 hours (FPH), Lane 5: 9 hours (FPH), Lane 6: 12 hours (FPH), Lane 7: 24 hours (FPH) 
Figure 2 shows the DPPH radical scavenging capacity of the pepsin and papain treated FPH in comparison to ascorbic acid where the highest DPPH radical scavenging activity $(\mathrm{P}<0.05)$ was reported in pepsin treated hydrolysates.

TBARS assay is widely used in scientific researches to quantify the level of lipid peroxidation by means of measuring malondialdehyde concentration (MDA), which is formed as the end product of oxidation of polyunsaturated fatty acids caused by free radical-induced reactions (Oakes and Van Der Kraak, 2003). As shown in Table 1, there was a significant difference $(\mathrm{P}<0.05)$ in TBARS values among hydrolysates, where the highest lipid peroxidation was observed in the papain treated hydrolysates. TBARS values of all the hydrolysates were significantly higher $(\mathrm{P}<0.05)$ than the control sample (oil emulsion).

These observations revealed that the pepsin $(0 \mathrm{~h})$ treated FPH contains high antioxidant properties compared to the papain $(9 \mathrm{~h})$ treated FPH. Since these FPHs are less efficient in retardation of malonaldehyde formation, they should not be incorporated into high lipid-containing foods. Because of derived peptides of hydrolysates is lack in exhibiting antioxidative properties, it might cause lipid oxidation followed by development of rancid aroma due to formation of secondary products including malonaldehyde, ketones, esters and aldehydes. The first known scientific study of antioxidant activity of FPH was reported in 1995. Since then, many studies demonstrated the antioxidant activity of peptides isolated from various FPH (Shahidi et al., 1995).

\section{Metal chelation properties}

Metal chelating activity of peptides is beneficial in increasing of bioavailability of minerals, which retards oxidation of food (Hebert et al., 2010). It is useful in the food and pharmaceutical industry as a carrier of micronutrients, which facilitate their absorptions in the digestive system (Guo et al., 2014). As demonstrated in Figure 3, no significant difference was observed between metal chelating activity of two hydrolysates produced from pepsin $(0 \mathrm{~h})(52.31 \% \pm 0.93)$ and papain (9 h) (50.95\% $\%$ 1.17) ( $>>0.05)$. Besides, pepsin treated FPH showed comparatively high iron (Fe (II)) chelating activity. The results indicated that protein hydrolysates had a noticeable capacity for ironbinding strength.

Antioxidant capacity of bioactive peptides can be attributed to their metal ion chelation properties, radical scavenging and inhibition of lipid
Table 1. TBARS assay of FPH

\begin{tabular}{lc}
\hline Hydrolysates & $\begin{array}{c}\text { TBARS value } \\
\text { (MDA mg/ L) }\end{array}$ \\
\hline Pepsin & $0.087 \pm 0.05^{\mathrm{b}}$ \\
Papain & $0.117 \pm 0.09^{\mathrm{a}}$ \\
Control & $0.045 \pm 0.09^{\mathrm{c}}$ \\
\hline
\end{tabular}

†Values with the same letters are not significantly different at $\mathrm{p}<0.05$.

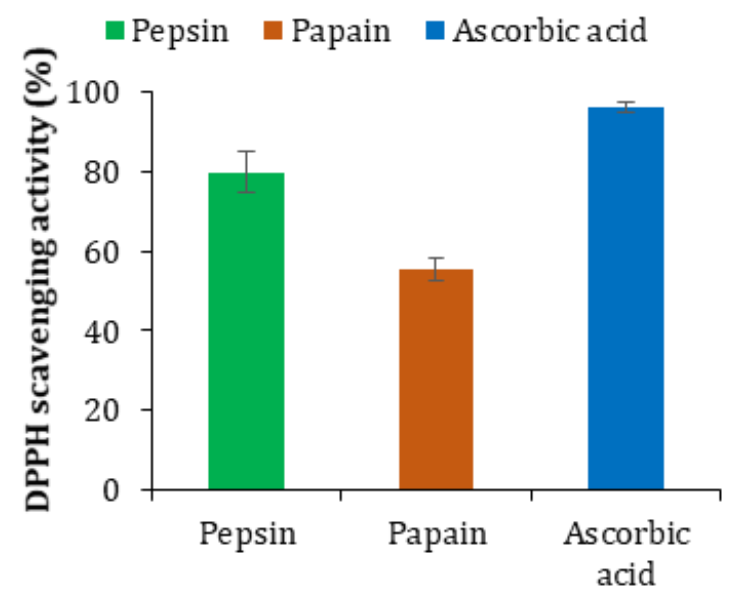

Fish protein hydrolysates

Figure 2. DPPH Radical Scavenging activity of fish hydrolysates produced from pepsin $(0 \mathrm{~h})$ and papain $(9 \mathrm{~h})$ enzymatic hydrolysis

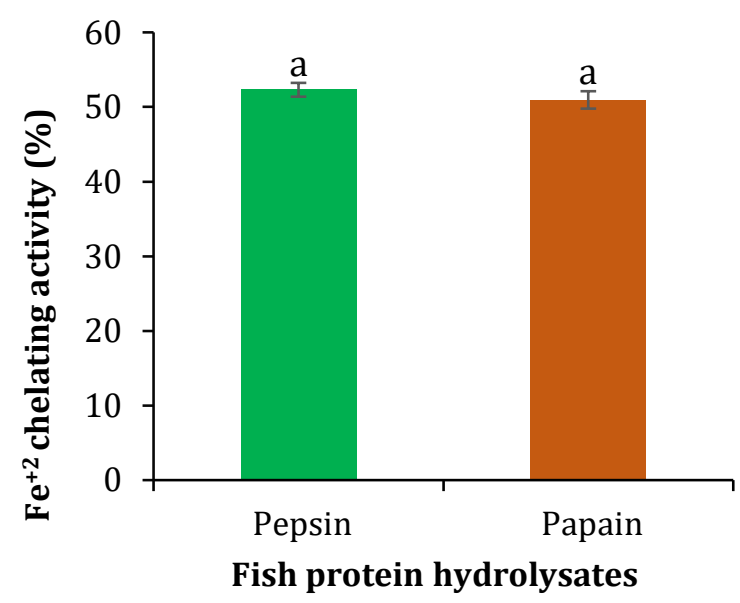

Figure 3. Ferrous (Fe (II)) chelating activity of fish hydrolysates produced from pepsin $(0 \mathrm{~h})$ and papain $(9 \mathrm{~h})$ enzymatic hydrolysis

peroxidation of peptides. Sarmadi and Ismail, 2010 proposed that the structure of the resulting peptides, its amino acid sequence and the size can affect the antioxidant properties. According to them, the chelating activity was positively correlated with the histidine content of the purified 


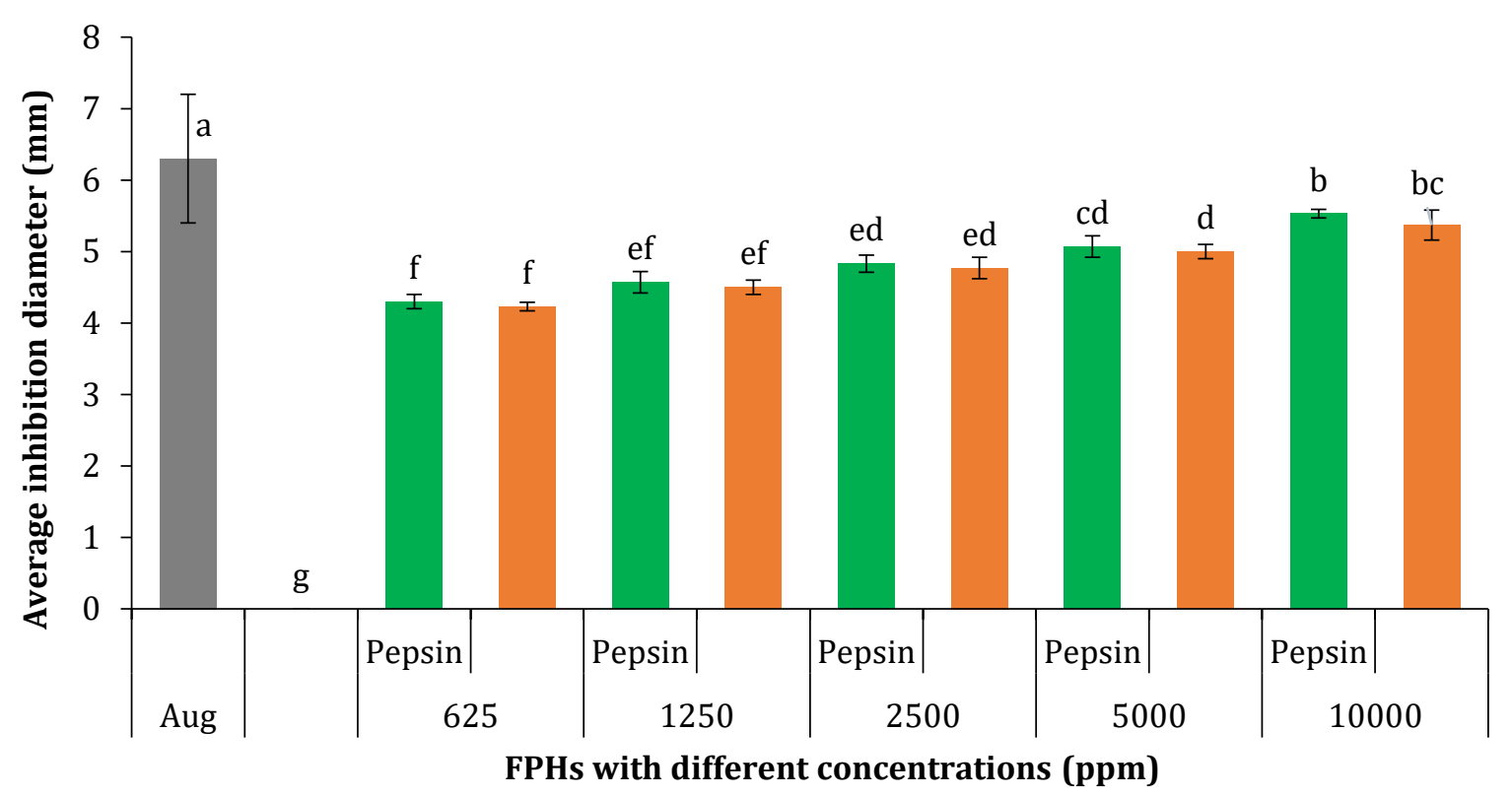

Figure 4. Antimicrobial activity of FPHs. Note: Aug: Augmentin (Positive control), DW: Autoclaved distilled water (Negative control)

fractions of a chickpea protein hydrolysate, and the small peptide size is with the best chelating activities.

In the current study, it was revealed that the considerably low iron binding ability of both FPHs derived from acid soluble P. pardalis FPE. Hence, the results of TBARS assay and Fe (II) chelating activity are similar in the present study. As transitional metal ions, such as Fe (II) can catalyze the generation of reactive oxygen species that oxidize unsaturated lipids (Stohs and Bagghi, 2005).

\section{Antimicrobial properties}

Fish protein-derived peptides demonstrate different types of antimicrobial properties. These peptides are positively charged, short amino-acidchain molecules that are involved in host defense mechanisms and play a vital role in natural immunity by interacting directly with bacteria and killing them (Zhang et al., 2008). According to the results of the present study, all the concentrations of FPHs exhibited clear inhibition zones even at the lowest concentrations of both the treatments. The two treatments (enzymes) at all the concentrations were not significantly different $(p>0.05)$ but were significantly different from positive control $(\mathrm{p}<0.05)$. Among the treatments, the highest concentration of pepsin treated FPH demonstrated the highest antibacterial activity. Diameter of inhibition increased with the increasing concentration of both treatments though there was no significant difference between the treatments. Antimicrobial activity of derived FPH was illustrated in Figure 4.

\section{CONCLUSION}

The FPH produced by enzymatic hydrolysis (papain (9 hours), pepsin (0 hour)) of acid extracted $P$. pardalis demonstrated strong antibacterial and antioxidant activities as favorable bioactive properties. Further, FPHs derived from $P$. pardalis showed a ferrous chelating activity which could indirectly strengthen the demonstrated antioxidant properties.

The results of the present study are compatible with the results of a previous study on antibacterial activity against $E$. coli and Listeria innocua, of FPHs produced using Sepia pharaonis (cuttlefish) ink extract and Scomber scombrus (Atlantic mackerel) by-products using commercial enzymes including papain, neutrase, flavoenzyme and protamex (Ennaas et al., 2015) 


\section{REFERENCES}

Abeyrathne, E.D.N.S., Lee, H.Y., Jo, C., Nam, K.C. and Ahn, D.U. (2014). Enzymatic hydrolysis of ovalbumin and the functional properties of the hydrolysates. Poultry Science. 93(10), 2678-2686.

Alasalvar, C., Shahidi, F. and Quantick, P. (2002). Food and health applications of marine nutraceuticals: A review. pp. 175-204. In: Alasalvar C., Taylor T. (Eds.) Sea Foods Quality, Technology and Nutraceutical Applications. Springer, Berlin, Heidelberg.

Bendjeddou, A., Abbaz, T., Ayari, A., Benahmed, M., Gouasmia, A. and Villemin, D. (2016). Antibacterial activity and global reactivity descriptors of some newly synthesized unsymmetrical sulfamides. Oriental Journal of Chemistry. 32(2), 799-806.

Béné, C., Barange, M., Subasinghe, R., PinstrupAndersen, P., Merino, G., Hemre, G. I., \& Williams, M. (2015). Feeding 9 billion by 2050-Putting fish back on the menu. Food Security. 7(2), 261-274.

Bhaskar, N., and Mahendrakar, N. S. (2008). Protein hydrolysate from visceral waste proteins of Catla (Catla catla): optimization of hydrolysis conditions for a commercial neutral protease. Bioresource Technology, 99 (10), 4105-4111.

Boye, J. I., Ma, C.Y., and Harwalkar, V.R., (1997). Thermal denaturation and coagulation of proteins. pp. 25-56. In: Damodaran S., Paraf A. (Eds.) Food Proteins and Their Applications. New York: Marcel Dekker.

Centenaro, G.S., Centenaro, M.S., and Hernandez, C.P. (2011). Antioxidant activity of protein hydrolysates of fish and chicken bones Advance Journal of Food Science and Technology. 3(4), 280-288.

Choi, Y.J. and Park, J.W. (2002). Acid-aided protein recovery from enzyme-rich Pacific whiting. Journal of Food Science. 67(8), 29622967.

Damodaran, S., Parkin, K.L. and Fennema, O.R., (2008). Amino acids, peptides and proteins. pp. 217-329. In: Damodaran S, Parkin K.L. (Eds.) Fennema's Food Chemistry. CRC Press, Boca Raton.

Ennaas, N., Hammami, R., Beaulieu, L. and Fliss, I. (2015). Purification and characterization of four antibacterial peptides from protamex hydrolysate of Atlantic mackerel (Scomber scombrus) by-products. Biochemical and
Biophysical Research Communications. 462(3), 195-200.

Fernando, C.H. (2000). A view of the inland fisheries of Sri Lanka: Past, present and future.Sri Lanka Journal of Aquatic Sciences. 5, 1-26.

Guo, L., Harnedy, P.A., Li, B., Hou, H., Zhang, Z., Zhao, X. and FitzGerald, R.J. (2014). Food proteinderived chelating peptides: Biofunctional ingredients for dietary mineral bioavailability enhancement. Trends in Food Science \& Technology. 37(2), 92-105.

Halldorsdottir, S.M., Sveinsdottir, H., Gudmundsdottir, A., Thorkelsson, G. and Kristinsson, H.G. (2014). High quality fish protein hydrolysates prepared from byproduct material with Fucus vesiculosus extract. Journal of Functional Foods. 9, 10-17.

Hebert, E.M., Saavedra, L. and Ferranti, P. (2010). Bioactive peptides derived from casein and whey proteins. pp. 233-249. In: Mozzi F, Raya R.R., Vignolo G.M., (Eds.) Biotechnology of Lactic Acid Bacteria: Novel Applications. Oxford: Wiley.

Hrynets, Y., Omana, D.A., Xu, Y. and Betti, M. (2011). Impact of citric acid and calcium ions on acid solubilization of mechanically separated turkey meat: Effect on lipid and pigment content. Poultry Science. 90(2), 458-466.

Hu, J., Arantes, V., Pribowo, A. and Saddler, J.N. (2013). The synergistic action of accessory enzymes enhances the hydrolytic potential of a -cellulase mixture; but is highly substrate specific. Biotechnology for Biofuels. 6(1):112.

Ingadottir, B. (2004). The use of acid and alkaliaided protein solubilization and precipitation methods to produce functional protein ingredients from Tilapia. Doctoral dissertation, University of Florida.

Jun, S.Y., Park, P.J., Jung, W.K. and Kim, S.K. (2004). Purification and characterization of an antioxidative peptide from enzymatic hydrolysate of yellowfin sole (Limanda aspera) frame protein. European Food Research and Technology. 219(1), 20-26.

Kristinsson, H.G. and Rasco, B.A. (2000). Fish protein hydrolysates: production, biochemical, and functional properties. Critical Reviews in Food Science and Nutrition. 40(1), 43-81.

Kumudinie, O. M. C. and Wijeyaratne, M. J. S. (2005). Feasibility of controlling the accidentally introduced invasive species Chitala ornata in Sri Lanka. Internationale Vereinigung für 
theoretische and angewandte Limnologie: Verhandlungen. 29 (2), 1025-1027.

Liu, Q., Kong, B., Xiong, Y.L. and Xia X. (2010). Antioxidant activity and functional properties of porcine plasma protein hydrolysate as influenced by the degree of hydrolysis. Food Chemistry. 118: 403-410.

Oakes, K.D. and Van Der Kraak, G.J. (2003). Utility of the TBARS assay in detecting oxidative stress in white sucker (Catostomus commersoni) populations exposed to pulp mill effluent. Aquatic Toxicology. 63(4), 447-463.

Ojutiku, R.O., Kolo, R.J. and Mohammed, M.L. (2009). Comparative study of sun drying and solar tent drying of Hyperopisus bebeoccidentalis. Pakistan Journal of Nutrition. 8(7), 955-957.

Perera, B.B.A.N.S., Aruppala A.L.Y.H. and Abeyrathne, E.D.N.S. Functional properties of salt extracted compounds from Pterygoplichthys pardalis (Amazon sailfin catfish). Wayamba International Conference (WinC) 2018. August 24-25, 2018. Pp 24.

Ramakrishnan, V.V., Ghaly, A.E., Brooks, M.S. and Budge, S.M. (2013). Extraction of proteins from mackerel fish processing waste using alcalase enzyme. Journal Bioprocessing Biotechniques. 3, 2-9.

Ramírez-Ramírez, J.C., Huerta, S., Arias, L., Prado, A. and Shirai, K. (2008). Utilization of fisheries by-catch and processing wastes for lactic acid fermented silage and evaluation of degree of protein hydrolysis and in vitro digestibility. Revista Mexicana de Ingeniería Química. 7(3), 195-204.

Rao, K. R. and Sunchu, V. (2017). A report on Pterygoplichthys pardalis Amazon sailfin sucker mouth catfishes in freshwater tanks at Telangana state, India. International Journal of Fisheries and Aquatic Studies. 5(2), 249254.

Sambrook, J. and Russell, D.W. (2006). Detection of protein-protein interactions using the GST fusion protein pulldown technique. Cold Spring Harbor Protocols. 2006(1), 3757.

Sarmadi, B.H. and Ismail, A. (2010). Antioxidative peptides from food proteins: A review. Peptides. 31(10), 1949-1956.

Shahidi, F., Han, X. and Synowiecki. J. (1995). Production and characteristics of protein hydrolysates from capelin (Mallotus villosus). Food Chemistry. 53, 285- 293.

Stohs, S.J. and Bagghi, D. (2005). Oxidative mechanisms in the toxicity of metal ions. Free Radical Biology and Medicine. 39(10), 12671268.

Tacon, A.G. and Metian, M. (2013). Fish matters: importance of aquatic foods in human nutrition and global food supply. Reviews in Fisheries Science. 21(1), 22-38.

Venugopal, V., Shahidi, F. and Lee, T.C. (1995). Value-added products from underutilized fish species. Critical Reviews in Food Science \& Nutrition. 35(5), 431-453.

Welcomme, R.L. (1988). International introductions of inland aquatic species (No. 294). Food \& Agriculture Org.

Zhang, Y.X., Zou, A.H., Manchu, R.G., Zhou, Y.C. and Wang, S.F. (2008). Purification and antimicrobial activity of antimicrobial protein from brown-spotted grouper, Epinephelus fario. Journal of Zoological Systematics and Evolutionary Research. 29, 627-63. 